\title{
Bio-based biodegradable film to replace the standard polyethylene cover for silage conservation
}

\author{
Giorgio Borreani ${ }^{1}$ and Ernesto Tabacco \\ Department of Agricultural, Forest and Food Sciences (DISAFA), University of Torino, Largo Braccini 2, 10095 Grugliasco (Torino), Italy
}

\begin{abstract}
The research was aimed at studying whether the polyethylene (PE) film currently used to cover maize silage could be replaced with bio-based biodegradable films, and at determining the effects on the fermentative and microbiological quality of the resulting silages in laboratory silo conditions. Biodegradable plastic film made in 2 different formulations, MB1 and MB2, was compared with a conventional $120-\mu$ m-thick PE film. A whole maize crop was chopped; ensiled in MB1, MB2, and $\mathrm{PE}$ plastic bags, $12.5 \mathrm{~kg}$ of fresh weight per bag; and opened after $170 \mathrm{~d}$ of conservation. At silo opening, the microbial and fermentative quality of the silage was analyzed in the uppermost layer (0 to $50 \mathrm{~mm}$ from the surface) and in the whole mass of the silo. All the silages were well fermented with little differences in fermentative quality between the treatments, although differences in the mold count and aerobic stability were observed in trial 1 for the MB1 silage. These results have shown the possibility of successfully developing a biodegradable cover for silage for up to $6 \mathrm{mo}$ after ensiling. The MB2 film allowed a good silage quality to be obtained even in the uppermost part of the silage close to the plastic film up to $170 \mathrm{~d}$ of conservation, with similar results to those obtained with the PE film. The promising results of this experiment indicate that the development of new degradable materials to cover silage till 6 mo after ensiling could be possible.
\end{abstract}

Key words: corn silage, biodegradable film, bioplastic, silage quality

\section{INTRODUCTION}

The demand for agricultural plastic has greatly increased throughout the world over the last decade (around 15\% in the total world consumption of plastic) and reached 3.6 million tonnes of agricultural films in 2013 (Vittova, 2013). A large proportion of the plastics used in agriculture is constituted by polyethylene films,

Received March 6, 2014.

Accepted September 16, 2014.

${ }^{1}$ Corresponding author: giorgio.borreani@unito.it which are used on greenhouses and tunnels, as mulching to cover the soil, as bunker silage covers, and as bale-wrap films. The plastic used in agriculture in 2013 was $59 \%$ in Asia, $15 \%$ in Europe, $8 \%$ in Canada, the United States, and Mexico, and 6\% in Latin America. In Europe, approximately $45 \%$ of the plastic used in agriculture is destined for silage packaging, ranging from $20 \%$ in Italy to $80 \%$ in Nordic countries (Vittova, 2013). Whole-crop corn silage is the basic forage feed used in dairy and beef-cattle diets in several areas of North America and Europe, and it is commonly conserved in bunkers or pile covered with plastic to maintain anaerobiosis (Mahanna and Chase, 2003). Silage conservation depends on a combination of anaerobic environment and the acidification that occurs when a sufficient amount of lactic acid is produced by the population of lactic acid bacteria present on the forage at harvesting (Pahlow et al., 2003). Plastic films have been used since the early 1950s (Anonymous, 1953) to protect small field clamp silos from rain ingress, and by 1960 sheets were increasingly made from polyethylene $(\mathbf{P E})$, because of its suitable mechanical characteristics and low costs, to reach anaerobic conditions of the ensiled mass (Wilkinson et al., 2003). Silage bags, bale wraps, and plastic bunker silo covers are the main plastic-film products used on dairy farms. Nowadays, most of these films are made in low-density PE and, recently, in low-density $\mathrm{PE}$ coextruded with polyamides or ethylene vinyl alcohol (Borreani et al., 2007; Borreani and Tabacco, 2014). In a recent survey in northern Italy it was found that an average $10.3 \mathrm{~kg}$ of plastic was used yearly per cow, of which $3.9 \mathrm{~kg} / \mathrm{cow}$ was used to cover bunker silages (G. Borreani and E. Tabacco, unpublished data). These data are in agreement with those reported by Levitan et al. (2005) pertaining to the Central Leatherstocking-Upper Catskill Region in New York State, where $3.4 \mathrm{~kg}$ of plastic film was used yearly per cow as an indicator of dairy-film use. The disposal of PE sheeting could represent a potential environmental concern, because it is nonbiodegradable, difficult to recycle, and can basically be used only once (Kyrikou and Briassoulis, 2007). Bhatti (2010) reported that in the United States, agricultural plastics are rarely disposed correctly. Current disposal methods 
include dumping at a solid-waste transfer station, leaving it in the fields, and plowing it into the ground. Furthermore, it has been reported that some farmers throughout the world burn plastic films in an open fire directly on the farms (Holmes and Springman, 2009; Bhatti, 2010; Borreani et al., 2013). These plastics, when burned under uncontrolled fire conditions at low temperatures, release toxic volatile compounds, resulting in human and environmental exposure (Font et al., 2004). Furthermore, some agricultural-plastic-film categories may be intrinsically difficult to recycle, because they are commonly contaminated by soil, sand, silage, and other organic residues (Holmes and Springman, 2009). Thus, the cost of producing virgin materials is sometimes considered less than the cost of collecting, cleaning, sorting and processing postconsumer plastics (Briassoulis et al., 2013). In recent years, a great deal of attention has been focused on research to replace petroleum-based commodity plastics, in a cost-effective manner, with biodegradable materials that offer competitive mechanical properties (Vieira et al., 2011). An alternative way of disposing of agricultural plastic wastes is through biodegradation. Most experts define a fully biodegradable polymer as a polymer that can be completely converted, by microorganisms, into carbon dioxide, water, minerals, and microbial biomass, without leaving any potentially harmful substances in the environment (Kyrikou and Briassoulis, 2007). Biodegradable bioplastics are derived from biological sources, instead of petroleum, and are an increasing alternative to petroleum-based plastics (Momani, 2009). Bioplastics come from a wide range of sources, but many plant-based bioplastics are derived from food crops, among them starch (maize and potatoes) and oleaginous plants (rapeseed and sunflower). A wide variety of bioplastics exist, but only a few have been put into major commercial production (Momani, 2009). A starch-based polymer, also known as Mater-Bi (MB; Novamont SpA, Novara, Italy), is the first completely biodegradable and compostable bio-polymer ever invented (Bastioli, 1998), and it has recently been shown that it can be used to produce films of different thickness that might be suitable for covering silage (Borreani et al., 2010). Other alternatives to biodegradable plastic films to cover silage, represented by organic covers such as straw, apple pulp, or food-industry waste, have been studied and suggested to replace PE film (Brusewitz et al., 1991; Savoie et al., 2003). Brusewitz et al. (1991) evaluated a soybean-based spray on a biofilm for corn silage and found that the biofilm did not provide any more protection than no cover at all. Savoie et al. (2003) concluded that the organic covers, within the studied range of thickness (2.5 to $50 \mathrm{~mm}$ ), did not offer adequate protection for bunker silos, because air infil- trated through the organic covers to $180 \mathrm{~mm}$ below the surface in $42 \mathrm{~d}$, and considerable DM losses and high $\mathrm{pH}$ values were observed. In 1953 an anonymous author questioned whether concrete or woody tower silos be replaced by plastic film, and this led to the plastic era of bunker silos (Gordon et al., 1961). Nowadays, the question is whether it is time for bio-based biodegradable films as an alternative to plastic films to cover silage. Researches revealed a widespread capability to degrade $\mathrm{MB}$ among bacteria and fungi inhabiting agricultural soil and mature compost (Accinelli et al., 2012). Therefore, preliminary ensiling tests are needed to evaluate the effectiveness of MB-based film to cover silage, without being damaged by microbial activity during ensiling. Mainly for these reasons we decided to perform the present study indoors, to avoid the confounding effects of degradation occurring under natural rain- and sun-exposed conditions. The aim of this research was to evaluate 2 new bio-based biodegradable plastic films to cover maize silages, in pilot trials to establish their performances in indoor conditions, and to obtain guidelines to develop new biodegradable films for farm-scale experiments.

\section{MATERIALS AND METHODS}

Two trials were carried out at the experimental farm of the University of Turin in the western Po plain, northern Italy $\left(44^{\circ} 53^{\prime} \mathrm{N}, 7^{\circ} 41^{\prime} \mathrm{E}\right.$, altitude $232 \mathrm{~m}$ above sea level), on 2 maize stands (Arma, FAO class 700, NK Syngenta Seeds S.p.A., Madignano, Cremona, Italy) harvested as a whole crop, at about 45 and $55 \%$ milkline stages and at $33.5 \pm 0.06 \%$ and $34.5 \pm 0.51 \%$ on DM, respectively. Corn stands were planted on April 12 , 2012, at a theoretical planting density of 71,000 seeds/ha. Fertilizer was applied at a rate of $40 \mathrm{~kg} / \mathrm{ha}$ of $\mathrm{P}_{2} \mathrm{O}_{5}$ and $55 \mathrm{~kg} / \mathrm{ha}$ of $\mathrm{K}_{2} \mathrm{O}$ immediately before planting. An additional $160 \mathrm{~kg} /$ ha of $\mathrm{N}$ was top-dressed at the 6-leaf stage. Irrigation was provided by a sprinkler irrigation system on July 26 and August 17 at a rate of about $600 \mathrm{~m}^{3}$ of water/ha.

The forages were chopped on September 5 and 15, 2012 , with a precision forage harvester, to a $10-\mathrm{mm}$ theoretical length of cut, and ensiled in plastic bags without inoculant addition. A standard $120-\mu \mathrm{m}$-thick black-on-white PE film and 2 different $120-\mu \mathrm{m}$-thick milky-transparent Mater-Bi biodegradable plastic films (blown film processing, MB1, monolayer, and MB2, 3 coextruded layers of MB to improve mechanical properties and stability) were used to produce the silage bags for this experiment. Mater-Bi is a wholly compostable polymer based on a blend of at least $50 \%$ starch and a synthetic hydrophilic, degradable polyester. This material degrades under laboratory-compostable conditions 
as specified in ASTM D-6400 standard for the United States, and in the EN13432 and EN14995 standards for Europe (Novamont, 2014). The oxygen permeability of the plastic films, determined on the basis of the American Society for Testing and Materials (ASTM) standard method D 3985-81 (ASTM, 1981), was 1,196 $\mathrm{cm}^{3} / \mathrm{m}^{2}$ per $24 \mathrm{~h}$ at $0.1 \mathrm{mPa}$ at $23^{\circ} \mathrm{C}$ and $90 \%$ relative humidity for PE and $500 \mathrm{~cm}^{3} / \mathrm{m}^{2}$ per $24 \mathrm{~h}$ for MB1 and MB2. The water-vapor transmission rate of the films differed. Water-vapor transmission rate was determined on the basis of the ASTM F1249 (ASTM, 2013) and was $1.05 \mathrm{~g} / \mathrm{m}^{2}$ (per $24 \mathrm{~h}$ at $38^{\circ} \mathrm{C}$ and $90 \%$ relative humidity) for $\mathrm{PE}$ and $17.4 \mathrm{~g} / \mathrm{m}^{2}$ for MB1 and MB2. The bags were heat sealed with a plastic film sealer (FR400LC, Ferplast, Guarene, Italy) at the closed end and were equipped with a one-way valve for $\mathrm{CO}_{2}$ release. Each bag was inserted into a portion of a PVC tube (300$\mathrm{mm}$ diameter, 300-mm height, and 21-L volume) and filled with about $12.5 \mathrm{~kg}$ of fresh forage, which was compacted manually and secured with plastic ties, with 4 replications for each treatment. Each PVC tube was sealed at one end to avoid exposure to air on both ends. The density of the silage was $604 \pm 5.2$ and $593 \pm 4.6$ $\mathrm{kg}$ of fresh material per cubic meter for trial 1 and trial 2, respectively. The silos were stored at ambient temperature $\left(20\right.$ to $\left.22^{\circ} \mathrm{C}\right)$ indoors and opened after 170 and $167 \mathrm{~d}$ for trial 1 and trial 2 , respectively.

At silo opening, the first $50 \mathrm{~mm}$ of silage from the top of each silo was removed, subsampled (about $400 \mathrm{~g}$ out of $2 \mathrm{~kg}$ ), and analyzed separately. Then all the remaining silage from each silo was mixed thoroughly and subsampled for microbial, fermentative, and aerobicstability testing.

After sampling, the silages were subjected to an aerobic-stability test. Aerobic stability was determined by monitoring the temperature increases due to the microbial activity of the samples exposed to air. About $3 \mathrm{~kg}$ of each silo was allowed to aerobically deteriorate at room temperature $\left(22 \pm 1.6^{\circ} \mathrm{C}\right)$ in 17 -L polystyrene boxes (290-mm diameter and 260-mm height) for $14 \mathrm{~d}$. A single layer of aluminum foil was placed over each box to prevent drying and dust contamination but also to allow air penetration. The temperature of the room and of the silage was measured each hour by a data logger. Aerobic stability was defined as the number of hours the silage remained stable before rising more than $2{ }^{\circ} \mathrm{C}$ above room temperature (Ranjit and Kung, 2000). Other indices of aerobic stability were expressed as dT, which is the difference between silage temperature and ambient temperature; the maximum temperature rise $\left({ }^{\circ} \mathrm{C}\right)$; and the number of hours necessary to reach the maximum temperature rise (peak temperature). The silage was sampled after $7 \mathrm{~d}$ of aerobic exposure to quantify the microbial and fermentative changes of the silage during exposure to air.

\section{Sample Preparation and Analyses}

The preensiled herbage and the silage were split into 4 subsamples. One subsample was oven dried at $65^{\circ} \mathrm{C}$ to constant weight to determine the DM content, air equilibrated, weighed, and ground in a Cyclotec mill (Tecator, Herndon, VA) to pass a 1-mm screen. The dried samples were analyzed for $\mathrm{CP}($ total $\mathrm{N} \times 6.25)$ by Kjeldahl method; for NDF content, using heat-stable amylase (A3306, Sigma Chemical Co., St. Louis, MO) and ADF content according to Robertson and Van Soest (1981); for starch concentration, according to the methods of the AOAC International (2005) using a K-AMYL assay kit (Megazyme International, Bray, Ireland); and for ash by ignition to $550^{\circ} \mathrm{C}$. A second subsample was extracted using a Stomacher blender (Seward Ltd., Worthing, UK) for $4 \mathrm{~min}$ in distilled water at a ratio of water to sample material (fresh weight) of 9:1. The total nitrate $\left(\mathrm{NO}_{3}\right)$ concentration was determined in the water extract, through semiquantitative analysis, using Merckoquant test strips (Merck, Darmstadt, Germany; detection limit of $100 \mathrm{mg}$ of $\mathrm{NO}_{3} / \mathrm{kg}$ ). The ammonia nitrogen $\left(\mathrm{NH}_{3}-\mathrm{N}\right)$ content and $\mathrm{pH}$, determined using specific electrodes, were quantified in the water extract. A third subsample was extracted using a Stomacher blender for 4 min in $\mathrm{H}_{2} \mathrm{SO}_{4} 0.05 \mathrm{~mol} / \mathrm{L}$ at a ratio of acid to sample material (fresh weight) of 5:1. The lactic and monocarboxylic acids (acetic, propionic, and butyric acids) were determined by HPLC in the acid extract (Canale et al., 1984). Ethanol and 1,2 propanediol were determined by HPLC, coupled to a refractive index detector, on an Aminex HPX-87H column (Bio-Rad Laboratories, Richmond, CA).

The fourth subsample was used for the microbiological analyses and water activity $\left(\mathbf{a}_{\mathrm{w}}\right)$. The $\mathrm{a}_{\mathrm{w}}$ was measured at $25^{\circ} \mathrm{C}$ using an AquaLab Series 3TE (Decagon Devices Inc., Pullman, WA) on a fresh sample. For the microbial counts, $30 \mathrm{~g}$ of sample was transferred into a sterile homogenization bag, suspended 1:10 wt/vol in a peptone salt solution (1 $\mathrm{g}$ of bacteriological peptone and $9 \mathrm{~g}$ of sodium chloride per liter), and homogenized for 4 min in a laboratory Stomacher blender. Serial dilutions were prepared, and the mold and yeast numbers were determined using the pour plate technique with $40.0 \mathrm{~g} / \mathrm{L}$ of yeast extract glucose chloramphenicol agar (YGC agar, Difco, West Molesey, Surrey, UK) after incubation at $25^{\circ} \mathrm{C}$ for 3 and $5 \mathrm{~d}$ for yeast and mold, respectively. Mold and yeast colony forming units were enumerated separately, according to their macromorphological features, on plates that yielded 1 to $100 \mathrm{cfu}$. 
The lactic acid bacteria were determined on MRS agar (Merck, Whitehouse Station, NY) with added natamycin $(0.25 \mathrm{~g} / \mathrm{L})$, by incubating Petri plates at $30^{\circ} \mathrm{C}$ for 3 d under anaerobic conditions, according to Spoelstra et al. (1988).

\section{Statistical Analysis}

The microbiological counts were $\log _{10}$ transformed and were presented on a wet-weight basis. The values below the detection limit for yeast and mold (detection levels: $10 \mathrm{cfu} / \mathrm{g}$ of silage) were assigned a value corresponding to half of the detection limit to calculate the average. The fermentative characteristics, microbial counts, and aerobic stability indices were analyzed separately for the 2 trials and for the different sampling zones. The fermentative and microbial characteristics were analyzed for their statistical significance via ANOVA, with their significance reported at a 0.05 probability level, of the Statistical Package for Social Science (v 17.0, SPSS Inc., Chicago, IL). When the calculated values of $F$ were significant, the Tukey test $(P<0.05)$ was used to interpret any significant differences among the mean values.

\section{RESULTS}

Table 1 lists the main characteristics of the forage before ensiling. The DM content, CP, starch, and NDF contents were typical of whole maize forage harvested at $50 \%$ of the milk line. Microbial counts of yeasts, molds, and lactic acid bacteria were greater than $6 \log _{10}$ $\mathrm{cfu} / \mathrm{g}$.

The fermentative and microbiological characteristics of the whole silage mass in the silo, after $170 \mathrm{~d}$ of conservation, are shown in Table 2. All the silages were well fermented, with $\mathrm{pH}$ below 3.9 in all the treatments in both trials. The main fermentation products were lactic and acetic acids, whereas butyric acid was below the detection limit (less than $0.01 \mathrm{~g} / \mathrm{kg}$ of $\mathrm{DM}$ ) in all the silages. Lactic acid was lower in MB1 than in MB2 and PE silages in trial 1. Propionic acid, ethanol, and 1,2 propanediol were present in all silages. Lactic acid bacteria did not show any differences between treatments in both trials. The yeast count was below $3 \log _{10}$ $\mathrm{cfu} / \mathrm{g}$ in PE and MB2 silages in both trials, whereas it reached $4.59 \pm 0.60$ and $3.17 \pm 0.39 \log _{10} \mathrm{cfu} / \mathrm{g}$ in MB1 silage for trials 1 and 2, respectively. Mold count was higher in MB1 silage than in PE and MB2 silages in trial 1, whereas it was similar between treatments in trial 2.

The fermentative and microbiological characteristics of the silages in the upper 0 to $50 \mathrm{~mm}$ close to the sealing film, after $170 \mathrm{~d}$ of conservation, are shown in Table 3. The DM content was greater in the MB1 and MB2 silages than in the PE silages in both trials, with values greater than $50 \%$ DM. This loss of moisture from the silages under the MB films caused a reduction in $\mathrm{a}_{\mathrm{w}}$ compared with PE. Dry matter values and $\mathrm{a}_{\mathrm{w}}$ were numerically lower than those observed in the whole mass of silage (Table 2).

The quality of the silages after $7 \mathrm{~d}$ of aerobic exposure and the aerobic stability indices are reported in Table 4. Three of the four MB1 silages in trial 1 had some parts that were visually moldy also below $50-\mathrm{mm}$ top layer. The quality profiles of the silages after air exposure showed a better quality for the MB2 silages, with a lower $\mathrm{pH}$ and greater amounts of lactic acid than the MB1 and PE silages in trial 1, whereas differences were observed only for lactic acid in silages for trial 2 . The highest values of aerobic stability were observed in MB2. Polyethylene showed intermediate values, and the lowest values were those of the MB1 silages. The evolution of dT during the aerobic stability tests

Table 1. Chemical and microbial composition of corn forages before ensiling ${ }^{1}$

\begin{tabular}{|c|c|c|}
\hline Item $^{2}$ & Trial 1 & Trial 2 \\
\hline $\mathrm{DM}(\%)$ & $33.5 \pm 0.06$ & $34.5 \pm 0.51$ \\
\hline $\mathrm{CP}(\%$ of $\mathrm{DM})$ & $7.8 \pm 0.18$ & $7.5 \pm 0.16$ \\
\hline Starch (\% of DM) & $32.2 \pm 1.02$ & $33.0 \pm 0.39$ \\
\hline NDF (\% of DM) & $42.1 \pm 0.59$ & $42.4 \pm 0.33$ \\
\hline $\mathrm{ADF}(\%$ of $\mathrm{DM})$ & $22.7 \pm 0.40$ & $23.3 \pm 0.29$ \\
\hline $\operatorname{Ash}(\%$ of DM) & $4.7 \pm 0.03$ & $4.5 \pm 0.02$ \\
\hline Nitrate (mg/kg of herbage) & $433 \pm 84.8$ & $374 \pm 46.1$ \\
\hline$a_{w}$ & $0.991 \pm 0.001$ & $0.990 \pm 0.002$ \\
\hline $\mathrm{pH}$ & $5.87 \pm 0.01$ & $5.95 \pm 0.03$ \\
\hline LAB ( $\log _{10} \mathrm{cfu} / \mathrm{g}$ of herbage) & $7.22 \pm 0.09$ & $7.15 \pm 0.19$ \\
\hline Yeasts ( $\log _{10} \mathrm{cfu} / \mathrm{g}$ of herbage) & $6.48 \pm 0.16$ & $6.19 \pm 0.17$ \\
\hline Molds ( $\log _{10} \mathrm{cfu} / \mathrm{g}$ of herbage) & $6.40 \pm 0.04$ & $6.11 \pm 0.12$ \\
\hline
\end{tabular}


Table 2. Fermentation and microbiological characteristics of the whole silage mass stored under different plastic films after $170 \mathrm{~d}$ of indoor conservation $^{1}$

\begin{tabular}{|c|c|c|c|c|c|c|c|c|c|c|}
\hline \multirow{2}{*}{ Item $^{2}$} & \multicolumn{5}{|c|}{ Trial 1} & \multicolumn{5}{|c|}{ Trial 2} \\
\hline & \multicolumn{3}{|c|}{ Plastic film } & SEM & $P$-value & \multicolumn{3}{|c|}{ Plastic film } & SEM & $P$-value \\
\hline DM (\%) & $32.1^{\mathrm{b}}$ & $32.9^{\mathrm{b}}$ & $34.5^{\mathrm{a}}$ & 4.26 & 0.022 & $33.5^{\mathrm{b}}$ & $37.6^{\mathrm{a}}$ & $36.7^{\mathrm{a}}$ & 6.51 & $<0.001$ \\
\hline $\mathrm{pH}$ & 3.66 & 3.82 & 3.61 & 0.04 & 0.089 & 3.78 & 3.74 & 3.81 & 0.02 & 0.351 \\
\hline$a_{\mathrm{w}}$ & 0.989 & 0.991 & 0.992 & 0.001 & 0.767 & 0.988 & 0.991 & 0.991 & 0.001 & 0.392 \\
\hline Butyric acid (g/kg of DM) & $<0.01$ & $<0.01$ & $<0.01$ & - & - & $<0.01$ & $<0.01$ & $<0.01$ & 1.0 & - \\
\hline Propionic acid (g/kg of DM) & 2.30 & 1.83 & 2.01 & 0.12 & 0.335 & $1.99^{\mathrm{a}}$ & $1.01^{\mathrm{c}}$ & $1.47^{\mathrm{b}}$ & 0.15 & 0.005 \\
\hline 1,2 -Propanediol $(\mathrm{g} / \mathrm{kg}$ of $\mathrm{DM})$ & 0.43 & 0.33 & 0.30 & 0.04 & 0.454 & 0.46 & 0.38 & 0.33 & 0.03 & 0.431 \\
\hline Ethanol ( $\mathrm{g} / \mathrm{kg}$ of DM) & $2.87^{\mathrm{a}}$ & $0.97^{\mathrm{b}}$ & $1.51^{\mathrm{b}}$ & 0.31 & 0.006 & 2.77 & 2.33 & 2.22 & 0.23 & 0.648 \\
\hline Lactic-to-acetic acid ratio & $2.2^{\mathrm{b}}$ & $2.0^{\mathrm{b}}$ & $3.1^{\mathrm{a}}$ & 0.20 & 0.041 & 2.0 & 3.1 & 2.3 & 0.24 & 0.157 \\
\hline Nitrate (mg/kg of silage) & 49 & 48 & 107 & 27.2 & 0.660 & 96 & 111 & 44 & 18.5 & 0.343 \\
\hline $\mathrm{NH}_{3}-\mathrm{N}(\%$ of DM) & 0.37 & 0.38 & 0.45 & 0.05 & 0.298 & $0.95^{\mathrm{a}}$ & $0.52^{\mathrm{b}}$ & $0.62^{\mathrm{b}}$ & 0.07 & 0.048 \\
\hline
\end{tabular}

${ }^{\mathrm{a}-\mathrm{c} I n}$ the same row within trial, means with the same superscript are not significantly different $(P<0.05)$.

${ }^{1} \mathrm{MB} 1$ = bio-based plastic film with Mater-Bi (Novamont SpA, Novara, Italy) blend 1; MB2 = bio-based plastic film with Mater-Bi blend 2; PE $=$ commercial plastic film with polyethylene.

${ }^{2} \mathrm{a}_{\mathrm{w}}=$ water activity; $\mathrm{NH}_{3}-\mathrm{N}=$ ammonia nitrogen; $\mathrm{LAB}=$ lactic acid bacteria.

is reported in Figure 1. The delay in the temperature increase in the MB2 silages, compared with the PE and MB1 silages, was evident in both trials.

The 2 biodegradable films (MB1 and MB2) were also evaluated for suitability in disposal by composting. Preliminary results indicate that the films were degradable in standard laboratory biodegradation tests and in pilot composting systems. Physical fragmentation in the final compost measured in a pilot-scale composting test was more than $90 \%$ within 12 wk (S. Guerrini, Novamont, Novara, Italy, personal communication).

\section{DISCUSSION}

Over the last few decades, some concerns have been raised about handling used polyethylene film that was

Table 3. Fermentation and microbiological characteristics of the silages stored under different plastic films in the uppermost layer $(0$ to 50 mm from the surface) after $170 \mathrm{~d}$ of indoor conservation ${ }^{1}$

\begin{tabular}{|c|c|c|c|c|c|c|c|c|c|c|}
\hline \multirow{2}{*}{ Item $^{2}$} & \multicolumn{5}{|c|}{ Trial 1} & \multicolumn{5}{|c|}{ Trial 2} \\
\hline & \multicolumn{3}{|c|}{ Plastic film } & SEM & $P$-value & \multicolumn{3}{|c|}{ Plastic film } & SEM & $P$-value \\
\hline $\mathrm{DM}(\%)$ & $34.1^{\mathrm{b}}$ & $50.4^{\mathrm{a}}$ & $52.2^{\mathrm{a}}$ & 2.99 & 0.001 & $33.8^{\mathrm{b}}$ & $50.0^{\mathrm{a}}$ & $52.3^{\mathrm{a}}$ & 3.06 & 0.001 \\
\hline $\mathrm{pH}$ & 3.76 & 3.96 & 3.68 & 0.06 & 0.147 & $3.86^{\mathrm{a}}$ & $3.77^{\mathrm{b}}$ & $3.79^{\mathrm{ab}}$ & 0.02 & 0.045 \\
\hline$a_{\mathrm{w}}$ & $0.987^{\mathrm{a}}$ & $0.978^{\mathrm{b}}$ & $0.978^{\mathrm{b}}$ & 0.002 & 0.024 & $0.988^{\mathrm{a}}$ & $0.976^{\mathrm{b}}$ & $0.980^{\mathrm{b}}$ & 0.002 & 0.005 \\
\hline Butyric acid ( $\mathrm{g} / \mathrm{kg}$ of DM $)$ & $<0.01$ & $<0.01$ & $<0.01$ & - & - & $<0.01$ & $<0.01$ & $<0.01$ & - & - \\
\hline Propionic acid ( $\mathrm{g} / \mathrm{kg}$ of DM) & 1.22 & 1.85 & 1.34 & 0.32 & 0.749 & 1.51 & 2.50 & 0.80 & 0.51 & 0.459 \\
\hline 1.2-Propanediol ( $\mathrm{g} / \mathrm{kg}$ of DM) & 0.23 & 0.15 & 0.25 & 0.07 & 0.854 & $0.40^{\mathrm{a}}$ & $0.11^{\mathrm{b}}$ & $0.04^{\mathrm{b}}$ & 0.06 & 0.007 \\
\hline Ethanol $(\mathrm{g} / \mathrm{kg}$ of DM) & 2.08 & 0.75 & 1.21 & 0.35 & 0.321 & 2.29 & 0.64 & 0.86 & 0.37 & 0.139 \\
\hline Lactic-to-acetic acid ratio & $1.7^{\mathrm{b}}$ & $4.9^{\mathrm{a}}$ & $4.9^{\mathrm{a}}$ & 0.59 & 0.004 & $1.6^{\mathrm{b}}$ & $5.1^{\mathrm{a}}$ & $4.6^{\mathrm{a}}$ & 0.63 & 0.011 \\
\hline Nitrate (mg/kg of silage) & 0 & 60 & 122 & 26.4 & 0.170 & 47 & 82 & 91 & 15.4 & 0.538 \\
\hline $\mathrm{NH}_{3}-\mathrm{N}(\%$ of $\mathrm{DM})$ & 0.87 & 0.46 & 0.77 & 0.09 & 0.059 & 0.84 & 0.56 & 0.60 & 0.08 & 0.421 \\
\hline
\end{tabular}

\footnotetext{
${ }^{a-c}$ In the same row within trial, means with the same superscript are not significantly different $(P<0.05)$.

${ }^{1} \mathrm{MB} 1$ = bio-based plastic film with Mater-Bi (Novamont SpA, Novara, Italy) blend 1; MB2 = bio-based plastic film with Mater-Bi blend 2; PE $=$ commercial plastic film with polyethylene.
}

${ }^{2} \mathrm{a}_{\mathrm{w}}=$ water activity; $\mathrm{NH}_{3}-\mathrm{N}=$ ammonia nitrogen; $\mathrm{LAB}=$ lactic acid bacteria. 
Table 4. Fermentative and microbiological characteristics and aerobic stability indices of the whole silage mass stored under different plastic films after $7 \mathrm{~d}$ of aerobic exposure ${ }^{1}$

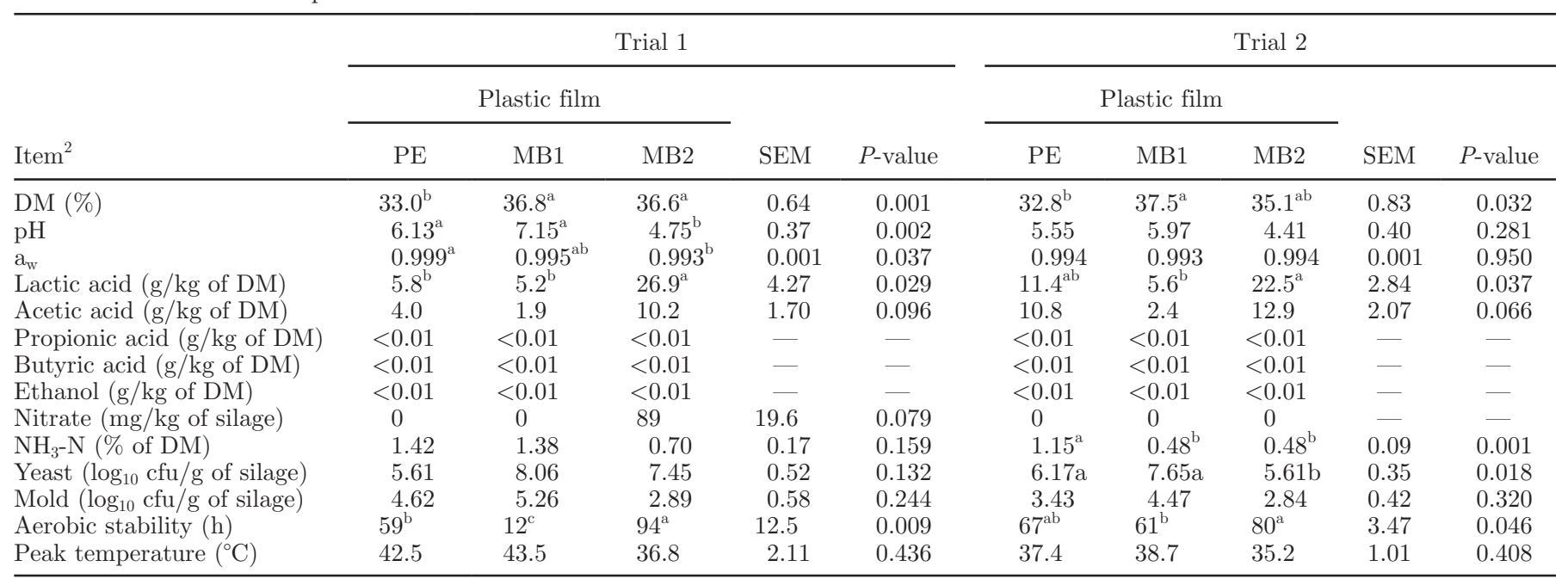

${ }^{\mathrm{a}-\mathrm{c}} \mathrm{In}$ the same row within trial, means with the same superscript are not significantly different $(P<0.05)$.

${ }^{1} \mathrm{MB1}$ = bio-based plastic film with Mater-Bi (Novamont SpA, Novara, Italy) blend 1; MB2 = bio-based plastic film with Mater-Bi blend 2; PE $=$ commercial plastic film with polyethylene.

${ }^{2} \mathrm{a}_{\mathrm{w}}=$ water activity; $\mathrm{NH}_{3}-\mathrm{N}=$ ammonia nitrogen.

used to cover silages, because it is nondegradable and difficult to recycle (Savoie et al., 2003; Briassoulis et al., 2013). Landfill and burning are the current disposal options for used plastic film, and finding new alternatives to conventional plastic films to cover silages is therefore necessary. Leaving silage uncovered is not a viable alternative because of the related large DM losses (Bolsen et al., 1993) and safety concerns (mycotoxins and harmful microorganism) due to silage aerobic deterioration that harms the fulfillments of the demands and criteria with respect to animal health, feed quality, and milk hygiene (Driehuis, 2013). Biodegradable coatings have been suggested to replace plastic film to seal horizontal bunker silos, but until now these materials have been unsuccessful in forming a stable barrier against air and the environment for longer periods than 1 mo (Brusewitz et al., 1991; Savoie et al., 2003; Denoncourt et al., 2007). The availability of new biodegradable polymers derived from different sources and the improved mechanical properties of the resulting films have opened a new opportunity in the management of bunker-silo coverings. Borreani et al. (2010), in a preliminary study, showed, for the first time, that biodegradable film could be a promising alternative to cover silages for conservation periods as long as 4 mo, and the results from that research suggested a thickness of at least $120 \mu \mathrm{m}$ to avoid degradation of the plastic film within a few months. This first experiment (Borreani et al., 2010) encouraged the development of a new blend, derived from renewable sources, which led to the production of blown films to cover silage. These films have been improved for the stability to microbial activity over time, and to have an oxygen permeability that is $41.8 \%$ lower than commercial PE films of the same thickness. The final goal in developing a new biodegradable plastic film to cover silage is to have a film that is stable to microbial and hydrolysis activities for periods of up to $12 \mathrm{mo}$, under natural rain- and sunexposed conditions, coupled with a high impermeability to oxygen (Borreani et al., 2013).

In the present experiment, 2 new bio-based biodegradable plastic films were evaluated to cover silages in pilot trials to establish their performances in indoor conditions, and to obtain guidelines to develop new biodegradable films for farm-scale experiments. The promising results, here reported, contributed to a step forward in the development of new biodegradable film that could protect silages for at least 5 mo.

A characteristic that separated these new films from the PE films was the water-vapor transmission rate, which was 10-fold greater in the MB films than in the PE film. The greater permeability to water vapor caused the silages covered with both the MB1 and MB2 films to wilt in the upper part, thus reaching DM concentration values greater than $50 \%$ in the uppermost layer of the silage in both trials, whereas it did not affect the fermentation profile. A drawback of this characteristic is that as moisture is lost, the porosity of silage increases, and this could allow a more rapid movement of oxygen back from the face of a bunker silo during feed-out. It could be speculated that, when the silo is opened, this problem could lead to more spoilage 


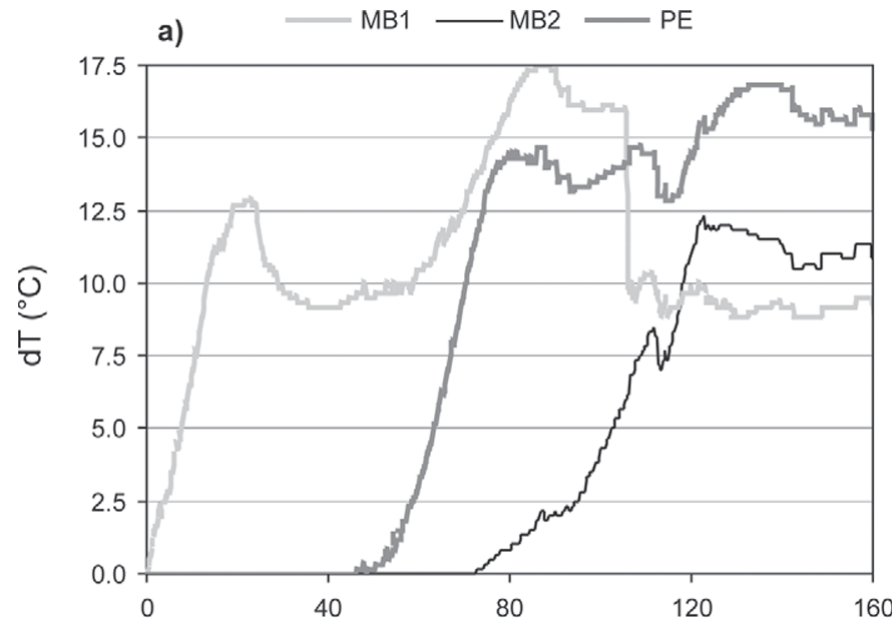

b)

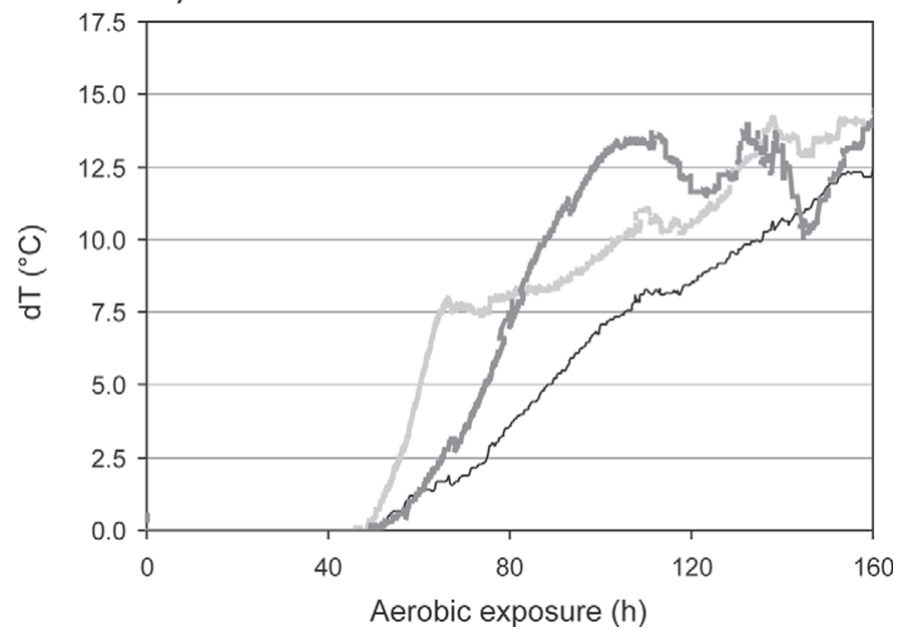

Figure 1. Evolution of dT (the difference between silage temperature and ambient temperature) in $\mathrm{PE}, \mathrm{MB} 1$, and $\mathrm{MB} 2$ silages during the aerobic-stability test in (a) trial 1 and (b) trial 2. MB1 = bio-based plastic film with Mater-Bi (Novamont SpA, Novara, Italy) blend 1 $\mathrm{MB} 2=$ bio-based plastic film with Mater-Bi blend 2; PE $=$ commercial plastic film with polyethylene.

under the film under farm conditions, even if the silage is more aerobically stable, and the improved aerobic stability observed for MB2 would offset the increased time of oxygen exposure before feeding caused by the higher DM content.

The most important single factor that can influence microbial and nutritional quality of a forage during ensiling is the degree of anaerobiosis reached in the complete silo and its maintenance for the whole conservation period (Borreani et al., 2007; Wilkinson and Davies, 2013). The maintenance of the mechanical characteristics and physical properties (i.e., oxygen impermeability) of a plastic film is a key factor in the preservation of forage quality in the top layer of horizontal silos (Borreani et al., 2007). If the airtight sealing of the silo is not appropriate, air penetrates the silage and aerobic microorganisms multiply, thus resulting in aerobic deterioration, and the DM losses in the top 0.5 $\mathrm{m}$ can exceed 35\% (Borreani et al., 2007). This results in losses of highly digestible DM (Bolsen et al., 1993), the possible production of mycotoxins (Garon et al., 2006), and the growth of pathogenic species (Ivanek et al., 2006), which make silage less palatable and produce metabolic disorders in dairy cows (Wilkinson, 1999). The MB2 film (due to the multilayer structure) showed good mechanical and physical properties that led to good silage conservation, even in the 50-mm upper layer of the silage. The lower oxygen permeabilities of the MB films were likely the reason for the improved aerobic stability for the MB2 silage in both trials, even though the acetic acid content was lower than that of the PE silages in trial 1. In agreement with Borreani et al. (2014) and Orosz et al. (2013), the findings from the current study show that a higher level of anaerobiosis over the conservation period could reduce yeast counts in silage below $2.0 \log _{10} \mathrm{cfu} / \mathrm{g}$, even when lower amounts of acetic acid (less than $20 \mathrm{~g} / \mathrm{kg}$ of DM) are produced (e.g., MB2 silages in trial 1), and could result in better aerobic stability for more than $90 \mathrm{~h}$. Some previous works reported that a better anaerobic environment under an oxygen-barrier film contributed to reducing yeast counts to below $2.0 \log _{10} \mathrm{cfu} / \mathrm{g}$ of silage (Dolci et al., 2011; Borreani et al., 2014) and consequently to increasing the aerobic stability of silages, as well as to delay temperature increase when the silage was exposed to air (as reported in Figures 1a and 1b). The whole mass of the silages covered with the biodegradable biobased film MB2 showed similar fermentative profiles to those conserved below the PE film, with a yeast count below $2.0 \log _{10} \mathrm{cfu} / \mathrm{g}$ of silage after $170 \mathrm{~d}$ of conservation for the MB2 film in both trials. The yeast count was markedly lower than the values reported by Denoncourt et al. (2007), who found a yeast count of up to $5.98 \log _{10} \mathrm{cfu} / \mathrm{g}$ in corn silage coated with a biodegradable coating after $70 \mathrm{~d}$ of conservation in laboratory silos under protected storage conditions. The MB1 film showed the worst results (i.e., the highest yeast count and the lowest aerobic stability) in trial 1, due to the beginning of degradation of the film in 3 silos out of 4 . This film degradation allowed oxygen to gain access to the silage and led to an alteration of the silage quality, with increased yeast and mold counts, in both the uppermost layer and in the whole mass of the silage. As previously observed by other researchers (Pahlow et al., 2003; Borreani and Tabacco, 2010), yeast activity likely depleted the lactic acid, which as a result was lower in MB1 than in the MB2 and PE silages in the whole mass. In trial 2, MB1 did not degrade till the end of the trial, and the silage conserved under it showed a good fermentation quality similar to that of the PE 
and MB2 silages. These results have confirmed that the maintenance of a high degree of anaerobiosis during conservation is crucial for silage quality (Woolford, 1990; Borreani et al., 2007).

Overall, data from this study showed that MB2 performed more consistently than MB1, and results suggested that this formulation is worthy of further study and could represent the first step for development of film that could be used for bunker-silo studies. The promising results found in this experiment indicate that the development of new degradable materials to cover silage could be possible. Further research should be undertaken to improve the MB blend to enhance film stability over time, and to evaluate biodegradable plastic films under outdoor conditions.

\section{ACKNOWLEDGMENTS}

The authors thank Sara Guerrini and Roberto Ponti (Novamont SpA, Novara, Italy) for the development of the biodegradable plastic films used in the experiment. They also thank Mauro Gilli and Mario Gilardi [Department of Agricultural, Forest and Food Sciences (DISAFA), University of Turin, Italy] for technical assistance in the field and Serenella Piano (DISAFA) for the chemical and microbiological analyses. This work was funded by the Regione Piemonte - POR. FESR 07-13-ASSE I.1.1 - Agroalimentare, Years 2011-2013 project "F\&F BIOPACK: FEED \& FOOD PACKAGING-Film biodegradabili per la sostenibilità ambientale della filiera agro-alimentare [Biodegradable films for the environmental sustainability of the agro-food chain]."

\section{REFERENCES}

Accinelli, C., M. L. Saccà, M. Mencarelli, and A. Vicari. 2012. Deterioration of bioplastic carrier bags in the environment and assessment of a new recycling alternative. Chemosphere 89:136-143.

Anonymous. 1953. Packaged silage: Will plastics replaced silos? New Jersey Agric. 35:4-5.

AOAC International. 2005. Official Methods of Analysis. 18th ed. AOAC International, Washington, DC.

ASTM. 1981. ASTM Standard method D 3985-81. Pages 607-612 in Annual Book of Standards. Am. Soc. Test. Mater., Philadelphia, PA.

ATSM. 2013. ATSM F1249-13, Standard test method for water vapor transmission rate through plastic film and sheeting using a modulated infrared sensor. ATSM International, West Conshohocken, PA.

Bastioli, C. 1998. Properties and application of Mater-Bi starch-based materials. Polym. Degrad. Stabil. 59:263-272.

Bhatti, J. A. 2010. Current state and potential for increasing plastics recycling in the U.S. MS Thesis. Columbia Univ. Sponsored by Earth Engineering Center. Accessed on Aug. 25, 2014. http:// www.seas.columbia.edu/earth/wtert/sofos/bhatti_thesis.pdf.

Bolsen, K. K., J. T. Dickerson, B. E. Brent, R. N. Sonon Jr., B. S. Dalke, C. Lin, and J. E. Boyer Jr. 1993. Rate and extent of top spoilage losses in horizontal silos. J. Dairy Sci. 76:2940-2962.
Borreani, G., S. Piano, and E. Tabacco. 2014. Aerobic stability of maize silage stored under plastic films with different oxygen permeability. J. Sci. Food Agric. 94:2684-2690.

Borreani, G., A. Revello Chion, S. Piano, F. Ranghino, and E. Tabacco. 2010. A preliminary study on new biodegradable films to cover silages. Pages 202-204 in Grassland in a Changing World. H. Schnyder, J. Isselstein, F. Taube, K. Auerswald, J. Schellberg, M. Wachendorf, A. Herrmann, M. Gierus, N. Wrage, and A. Hopkins, ed. Proc. 23rd Gen. Mtg. Eur. Grassl. Fed., Kiel, Germany. Mecke Druck und Verlag, Duderstadt, Germany.

Borreani, G., and E. Tabacco. 2010. The relationship of silage temperature with the microbiological status of the face of corn silage bunkers. J. Dairy Sci. 93:2620-2629.

Borreani, G., and E. Tabacco. 2014. Improving corn silage quality in the top layer of farm bunker silos through the use of a next generation barrier film with high impermeability to oxygen. J. Dairy Sci. 97:2415-2426.

Borreani, G., E. Tabacco, and L. Cavallarin. 2007. A new oxygen barrier film reduces aerobic deterioration in farm-scale corn silage. J. Dairy Sci. 90:4701-4706.

Borreani, G., E. Tabacco, S. Guerrini, and R. Ponti. 2013. Opportunities in developing novel biodegradable films to cover silages. Pages 4.1-4.13 in Proc. Agric. Film 2013. Appl. Mrkt. Info. Ltd., Madrid, Spain.

Briassoulis, D., M. Hiskakis, and E. Babou. 2013. Technical specifications for mechanical recycling of agricultural plastic waste. Waste Manag. 33:1516-1530.

Brusewitz, G. H., R. L. Huhnke, and E. M. Barnes. 1991. Performance of Nutri-shield in protecting bunker-stored silage. Appl. Eng. Agric. $7: 515-519$.

Canale, A., M. E. Valente, and A. Ciotti. 1984. Determination of volatile carboxylic acids $(C 1-C 5)$ and lactic acid in aqueous acid extracts of silage by high performance liquid chromatography. J. Sci. Food Agric. 35:1178-1182.

Denoncourt, P., S. Caillet, and M. Lacroix. 2007. Bacteriological and chemical changes occurring in bunker-stored silage covered with biodegradable coating. J. Appl. Microbiol. 103:261-270.

Dolci, P., E. Tabacco, L. Cocolin, and G. Borreani. 2011. Microbial dynamics during aerobic exposure of corn silage stored under oxygen barrier or polyethylene films. Appl. Environ. Microbiol. 77:7499-7507.

Driehuis, F. 2013. Silage and the safety and quality of dairy foods: A review. Agric. Food Sci. 22:16-34.

Font, R., I. Aracil, A. Fullana, and J. A. Conesa. 2004. Semivolatile and volatile compounds in combustion of polyethylene. Chemosphere 57:615-627.

Garon, D., E. Richard, L. Sage, V. Bouchart, D. Pottier, and P. Lebailly. 2006. Mycoflora and multimycotoxin detection in corn silage: Experimental study. J. Agric. Food Chem. 54:3479-3484.

Gordon, C. H., J. C. Derbyshire, W. C. Jacobson, E. A. Kane, C. G. Melin, and J. R. McCalmont. 1961. Comparisons of unsealed and plastic sealed silages for preservation efficiency and feeding value. J. Dairy Sci. 44:1113-1121.

Holmes, B. J., and R. Springman. 2009. Recycling silo-bags and other agricultural plastic films (A 3875). Cooperative Extension of the University of Wisconsin-Extension. Accessed Feb. 17, 2014. http:// www.uwex.edu/ces/crops/uwforage/A3875_Recycling_silo_bags_ and_other_ag_plastics.pdf.

Ivanek, R., Y. Gröhn, and M. Wiedmann. 2006. Listeria monocytogenes in multiple habitats and host populations: Review of available data for mathematical modeling. Foodborne Pathog. Dis. 3:319-336.

Kyrikou, I., and D. Briassoulis. 2007. Biodegradation of agricultural plastic films: A critical review. J. Polymer Environ. 15:125-150.

Levitan, L. C., D. G. Cox, and M. B. Clarvoe. 2005. Agricultural plastic film recycling: Feasibility and options in the Central Leatherstocking-Upper Catskill region of New York State. Envir. Risk Anal. Prog. (ERAP), Cornell Univ., Ithaca, NY. Accessed Feb. 17, 2014. http://ecommons.cornell.edu/bitstream/1813/33176/2/ AgFilmRecyFeasibility-05Red.pdf. 
Mahanna, B., and L. E. Chase. 2003. Practical applications and solutions to silage problems. Pages $855-895$ in Silage Science and Technology. Vol. 42. D. R. Buxton, R. E. Muck, and J. H. Harrison, ed. Am. Soc. Agron., Crop Sci. Soc. Am., Soil Sci. Soc. Am., Madison, WI

Momani, B. 2009. Assessment of the impacts of bioplastics: Energy usage, fossil fuel usage, pollution, health effects, effects on the food supply, and economic effects compared to petroleum based plastics. Worcester Polytech. Inst., Worcester, MA. Accessed Feb. 17, 2014. http://www.wpi.edu/Pubs/E-project/Available/ E-project-031609-205515/unrestricted/bioplastics.pdf.

Novamont, 2014. What's Mater-Bi ${ }^{\circledR}$. Accessed Aug. 27, 2014. http:// www.novamont.com/default.asp?id $=504$.

Orosz, S., J. M. Wilkinson, S. Wigley, Z. Bìrò, and J. Gallo. 2013. Microbial status, aerobic stability and fermentation of maize silage sealed with an oxygen barrier film. Agric. Food Sci. 22:182-188.

Pahlow, G., R. E. Muck, F. Driehuis, S. J. W. H. Oude Elferink, and S. F. Spoelstra. 2003. Microbiology of ensiling. Pages 31-93 in Silage Science and Technology. Vol. 42. D. R. Buxton, R. E. Muck, and J. H. Harrison ed. ASA, CSSA, SSSA, Madison, WI.

Ranjit, N. K., and L. Kung Jr. 2000. The effect of Lactobacillus buchneri, Lactobacillus plantarum, or a chemical preservative on the fermentation and aerobic stability of corn silage. J. Dairy Sci. $83: 526-535$.

Robertson, J. B., and P. J. Van Soest. 1981. The detergent system of analysis and its application to human foods. Pages $123-158$ in The
Analysis of Dietary Fiber in Food. W. P. T. James and O. Theander, ed. Marcel Dekker, New York, NY.

Savoie, P., M. Bernier-Roy, M.-L. Pedneault, and A. Amyot. 2003. Evaluation of apple pulp and peanut butter as alternative bunker silo covers. Can. Biosyst. Eng. 45:2.17-2.22.

Spoelstra, S. F., M. G. Courtin, and J. A. C. van Beers. 1988. Acetic acid bacteria can initiate aerobic deterioration of whole crop maize silage. J. Agric. Sci. 111:127-132.

Vieira, M. G. A., M. A. da Silva, L. Oliveira dos Santos, and M. M. Beppu. 2011. Natural-based plasticizers and biopolymer films: A review. Eur. Polym. J. 47:254-263.

Vittova, K. 2013. Latest developments and challenges in the agricultural film market. Pages 1-11 in Proc. Agric. Film 2013, Int. Indust. Conf. Silage, Mulch Tunnel Films Used Agric., Appl. Mrkt. Info. Ltd., Madrid, Spain.

Wilkinson, J. M. 1999. Silage and animal health. Nat. Toxins 7:221232.

Wilkinson, J. M., K. K. Bolsen, and C. J. Lin. 2003. History of silage. Pages 1-30 in Silage Science and Technology. Vol. 42. D. R Buxton, R. E. Muck, and J. H. Harrison ed. ASA, CSSA, SSSA, Madison, WI.

Wilkinson, J. M., and D. R. Davies. 2013. The aerobic stability of silage: Key findings and recent developments. Grass Forage Sci. $68: 1-19$.

Woolford, M. K. 1990. The detrimental effect of air on silage. J. Appl. Bacteriol. 68:101-116. 